\title{
A practical guide to diagnosis and management
}

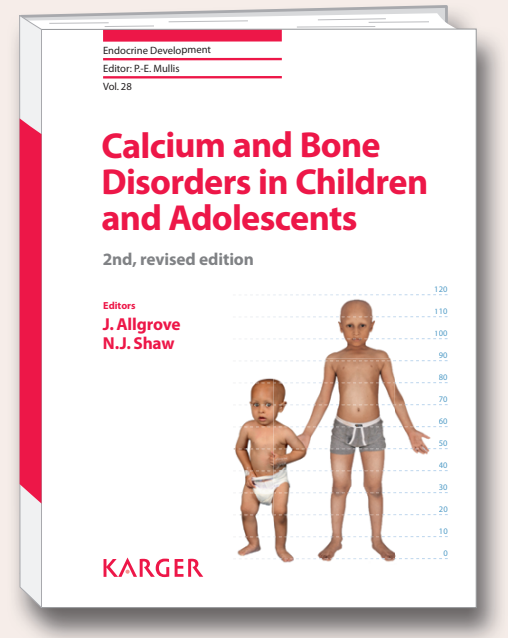

There has been a rapid expansion of knowledge in the field of paediatric calcium and bone disorders over the past twenty years. Advances have been made in the underlying genetic basis for many conditions in conjunction with progress in bone density and geometry imaging and the development of new treatment options.

The 2 nd revised edition of Calcium and Bone Disorders in Children and Adolescents presents up-todate information on many aspects included in the 1st edition such as the physiology, pathology, diagnosis and management of numerous conditions including a chapter of case histories illustrating clinical aspects. New chapters on skeletal dysplasias, the genetics of osteoporosis, radiological imaging of bone and a practical approach to a child with recurrent fractures are included.

Providing a comprehensive update, this book is a useful clinical resource for paediatricians and specialists in endocrinology, metabolic bone disease, nephrology, rheumatology, radiology, orthopaedics and clinical genetics who may be faced with a child with a calcium and/or bone disorder.

\author{
Editors \\ Jeremy Allgrove \\ Nick J. Shaw
}

\section{Contents}

Foreword: Whyte, M.P.

Preface: Allgrove, J.; Shaw, N.J.

- Voyages of Discovery: Allgrove, J.

- Physiology of Calcium, Phosphate, Magnesium and Vitamin D: Allgrove, J.

- Physiology of Bone: Grabowski, P.

- Radiology of Osteogenesis Imperfecta, Rickets and Other Bony Fragility States: Calder, A.D.

- Bone Densitometry: Current Status and Future Perspective: Crabtree, N.; Ward, $K$

- A Practical Approach to Hypocalcaemia in Children: Shaw, N.J.

- Approach to the Child with Hypercalcaemia: Davies, J.H.

- A Practical Approach to Vitamin D Deficiency and Rickets: Allgrove, J.; Shaw, N.J.

- A Practical Clinical Approach to Paediatric Phosphate Disorders: Imel, E.A.;

Carpenter, T.O.

- Primary Osteoporosis: Arundel, P.; Bishop, N.

- Osteoporosis in Children with Chronic Disease: Högler, W.; Ward, L.

- Genetics of Osteoporosis in Children: van Dijk, F.S.

- A Practical Approach to Children with Recurrent Fractures: Korula, S.; Titmuss, A.T.;

Biggin, A.; Munns, C.F.

- Miscellaneous Bone Disorders: Mughal, M.Z.; Padidela, $R$

- Skeletal Aspects of Non-Accidental Injury: Johnson, K.; Bradshaw, $\boldsymbol{K}$.

- Skeletal Dysplasias: An Overview: Offiah, A.C.

- Drugs Used in Paediatric Bone and Calcium Disorders: Cheung, M.S.

- Classification of Disorders of Bone and Calcium Metabolism: Allgrove, J.

- Case Histories: Katugampola, H.; Saraff, V.; Kumaran, A.; Allgrove, J.; Shaw, N.J.

- Appendices

- Author Index/ Subject Index

Fields of Interest:

Endocrinology; Pediatrics; Rheumatology; Anatomy, Metabolism,

Musculoskeletal System, Pediatric Endocrinology, Radiology

Calcium and Bone Disorders in

Children and Adolescents

2nd, revised edition

Editors: Allgrove, J. (London); Shaw, N.J. (Birmingham)

VIII + 434 p., 152 fig., 22 in color, 43 tab., 2015

CHF 247.00 / EUR 231.00 / USD 291.00 (hard cover)

CHF 296.00 / EUR 277.00 / USD 349.00 (online)

Online version for institutional purchase

Prices subject to change

EUR price for Germany, USD price for USA and Latin

America only

ISBN 978-3-318-05466-8 (hard cover)

e-ISBN 978-3-318-05467-5
KARGER 125 


\section{A problem-oriented series for both the general practitioner and the hospital physician}

\section{Endocrine Development}

Series Editor: Mullis, P.-E. (Bern)

ISSN 1421-7082 / e-ISSN 1662-2979

Listed in MEDLINE/PubMed

This series is devoted to specific areas of fetal, neonatal, pediatric and adolescent endocrinology. It addresses a wide range of relevant issues in the context of a well-defined subject and covers new areas of clinical and basic research. Clear evidence-based guidelines on clinical management by highly qualified basic and clinical scientists who present their clinically relevant recent findings are also provided. Bringing together experts from related disciplines such as fetal and perinatal medicine, epidemiology, public health, molecular endocrinology, radiology and adult endocrinology, the volumes cover a broad spectrum in endocrine development.

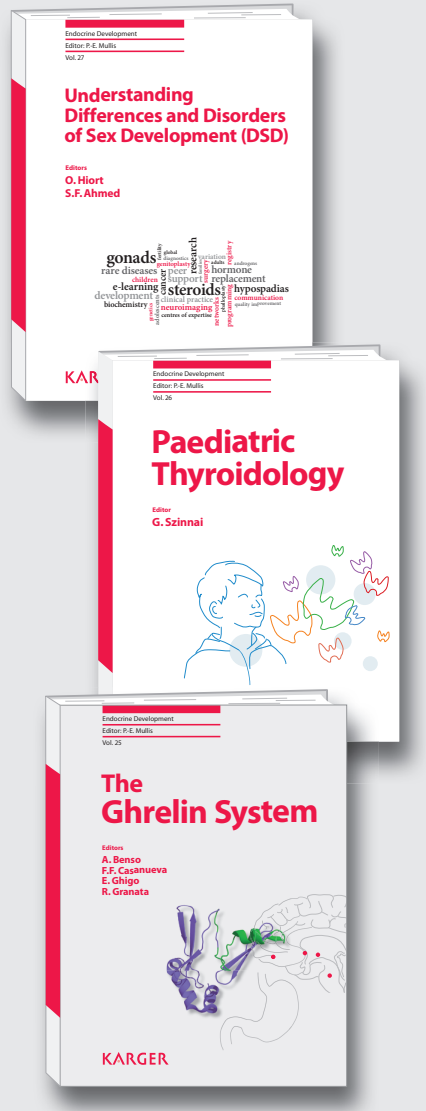

Back volumes

Vol. 27

Understanding Differences and Disorders of Sex Development (DSD)

Editors: Hiort, O. (Lübeck); Ahmed, S.F. (Glasgow)

$X+302$ p., 28 fig., 12 in color, 26 tab., 2014

CHF 198.00 / EUR 185.00 / USD 233.00 (hard cover)

CHF 238.00 / EUR 222.00 / USD 280.00 (online)

ISBN 978-3-318-02558-3 (hard cover)

e-ISBN 978-3-318-02559-0

Vol. 26

Paediatric Thyroidology

Editor: Szinnai, G. (Basel)

VIII + 252 p., 51 fig., 17 in color, 26 tab., 2014

CHF 198.00 / EUR 185.00 / USD 233.00 (hard cover)

CHF 238.00 / EUR 222.00 / USD 280.00 (online)

ISBN 978-3-318-02720-4 (hard cover)

e-ISBN 978-3-318-02721-1

Vol. 25

The Ghrelin System

Editors: Benso, A. (Turin); Casanueva, F.F. (Santiago de

Compostela); Ghigo, E. (Turin); Granata, R. (Turin)

VIII + 172 p., 16 fig., 2 in color, 4 tab., 2013

CHF 180.00 / EUR 168.00 / USD 212.00 (hard cover)

CHF 216.00 / EUR 202.00 / USD 254.00 (online)

ISBN 978-3-8055-9908-5 (hard cover)

e-ISBN 978-3-8055-9909-2

Vol. 1-24 available, please ask for details

Online version for institutional purchase

Prices subject to change

EUR price for Germany, USD price for USA only

\section{www.karger.com/endev}

Orders can be placed at agencies, bookstores, directly with the publisher, or with any Karger distributor.

S. Karger AG, P.O. Box, 4009 Basel (Switzerland)

f: +4161306 12 34, e: orders@karger.com

USA: S. Karger Publishers, Inc., 26 West Avon Road,

P.O. Box 529, Unionville, CT 06085

Toll free: +1-800-828-5479

Germany: S. Karger GmbH, 79095 Freiburg

France: Enter \& Read, Albertine Luginbuhl, 75014 Paris

Japan: Karger Japan, Inc., Tokyo 105-0012

South East Asia, China and Taiwan: Karger China, Shanghai 200001

\section{Order Form}

\section{Endocrine Development}

\section{Please send:}

_ copy/ies: Vol. 28: Calcium and Bone Disorders in Children and Adolescents 2nd, revised edition

CHF 247.00 / EUR 231.00 / USD 291.00

ISBN 978-3-318-05466-8

_ copy/ies: Vol. 27: Understanding Differences and Disorders of Sex Development (DSD) CHF 198.00 / EUR 185.00 / USD 233.00

ISBN 978-3-318-02558-3

_copy/ies: Vol. 26: Paediatric Thyroidology CHF 198.00 / EUR 185.00 / USD 233.00

ISBN 978-3-318-02720-4

_ copy/ies: Vol. 25: The Ghrelin System CHF 180.00 / EUR 168.00 / USD 212.00 ISBN 978-3-8055-9908-5

_ copy/ies:

ISBN 978-3-318-

$\square$ the book series Endocrine Development on continuation

beginning with vol.

$\square$ information on vols

All Karger series are available on continuation. Each volume will be sent upon publication until order is countermanded.

For easy ordering or further information about the series log on to: www.karger.com/endev

\section{Payment}

Postage and handling free with prepayment

Please charge this order to my credit card

$\square$ American Express $\square$ Diners

$\square$ Visa $\square$ MasterCard

Card No.:

Exp. date:

CW/CVC:

( 3 digits in the signature field on the back of Visa and MasterCard)

$\square$ Check enclosed $\quad \square$ Please bill me

Name/Address (please print): 